\title{
Increasing Destination Branding Through Destination Attributes and Tourism Promotion to Boost Visit Intention in Bromo Tengger Semeru National Park
} \author{
Sagita Hasanah ${ }^{4}$ \\ ${ }^{1}$ Faculty of Economics and Business, University of Jember, Jember, Indonesia \\ ${ }^{2}$ Faculty of Economics and Business, University of Jember, Jember, Indonesia \\ ${ }^{3}$ Akademi Komunitas Manajemen Perhotelan Indonesia (Mapindo), Bali, Indonesia \\ ${ }^{4}$ Faculty of Economics and Business, University of Jember, Jember, Indonesia \\ *Corresponding author. Email: ga.wulandari@unej.ac.id
}

Gusti Ayu Wulandari 1,*, Sudaryanto ${ }^{2}$, Gusti Ayu Agustina Riski ${ }^{3}$, Kamaliya

\begin{abstract}
This study analyses the effect of destination attributes and Tourism Promotion on Visit Intention on tourism visiting Bromo Tengger Semeru National Park through destination branding. The population in this study were tourists who visited the Bromo Tengger Semeru National Park. The sampling method used is by distributing questionnaires to respondents who have visited Bromo Tengger Semeru National Park. The variables used are as many as four variables. The analytical tool used is Path Analysis. The results of the study indicate that: 1) There is an influence of Destination Attributes and Tourism Promotion on Visit Intention to visit Bromo Tengger Semeru National Park; 2) There is an effect of destination branding on Visit Intention to visit Bromo Tengger Semeru National Park; 3) There is the influence of Destination Attributes and Tourism Promotion through the destination branding of Bromo Tengger Semeru National Park.
\end{abstract}

Keywords: Destination Attributes, Tourism Promotion, Destination Branding, Visit Intention.

\section{INTRODUCTION}

Tourism is an essential economic sector in Indonesia. According to Law Number 10 of 2009, tourism is a variety of tourism activities supported by various facilities and services provided by the community, business people, government and local governments. In 2019 before the pandemic, the tourism sector ranked third in terms of foreign exchange earnings. Natural and cultural wealth is an essential component of tourism in Indonesia. The Indonesian Minister of Tourism said that Indonesia's tourism growth was ranked ninth in the world according to The World Travel and Tourism Council (WTTC). However, after the pandemic, global tourism activities decreased dramatically in line with regulations aimed at stopping the pandemic from getting worse, so did Indonesia.
One of the famous landmarks in East Java is the Bromo Tengger Semeru National Park which contributed Rp 20.9 billion of non-tax state revenue (PNBP) in the pre-pandemic period. However, the pandemic has made tourism conditions drop dramatically so that in 2020 , the realization of the PNBP BTS achievement last year was only around Rp. 6.4 billion. With the pandemic, national income due to tourism activities, including at Bromo Tengger Semeru National Park (BTSNP) has dropped sharply to only $23 \%$. Therefore, it is necessary to increase the return of tourist visits to this national park to restore the economy of the country and the region in particular.

The number of visits at Bromo Tengger Semeru National Park (BTSNP) has a central role as a decision-maker to visit a particular tourist destination. Visit Intention is related to a purchase decision; before 
someone decides to visit, that person has made a purchase decision. Visit Intention or buying interest in a product in tourism can be interpreted as an encouragement that comes from someone's internal stimulation that motivates action, where the drive is influenced by the stimulus and positive feelings of products, services or places [1], [2], [3]. The main thing that can increase interest in visiting a tourist attraction is the destination branding activity carried out by the manager [4], [5], [6], [7] , so that a destination becomes more recognizable and attractive to tourists

In today's highly competitive market, many destinations- from individual resorts to countriesadopt branding techniques similar to those used by manufactured products [7]. In particular, destination branding is defined narrowly for many practitioners in destination management organizations (DMOs). However, it does not adequately represent a tourist destination and provide good literature of the place itself [8]. The place should concentrate more on product development and tourism marketing to improve place images (especially in the tourism sector). A theoretical model of destination branding integrates the branding and destination image [9]. The evaluation measures for branding destinations are presence, place, potential, pluses, people, and prerequisites.

Destination attributes can affect the interest in visiting a tourist destination [10], [11], [12] and even the interest to visit again [13], [14], [15] . Destination attributes are the overall services obtained and felt or enjoyed by tourists in the tourist destinations visited [16], [17], [18]. Tourism product attributes are represented by four indicators, namely destination attraction, destination facilities, accessibility, and images [18], [19]. The attractiveness of tourist destinations is the primary motivation for tourists to make tourist visits. BTSNP itself is one of the best locations in Indonesia to see the sunrise. Some location points that become BTSNP tourist attractions are Mount Semeru, Ranu Pani and Ranu Kumbolo, Penanjakan, Bromo Crater, Whispering Sand, Teletubies Hill, Tengger culture itself and others. Destination facilities, namely BTSNP, are quite capable, especially around Mount Bromo, such as clean inns and other public facilities. Accessibility to several location points has become easier to reach in several locations, especially in the Penanjakan area, Ranu Pani and Bromo Crater itself. In contrast, for some climbing points and others, it is deliberately unspoiled to preserve nature and the essence of the national park itself. BTSNP is a mainstay ecotourism product in the East Java region which does not doubt the pictures that present the enchanting natural beauty.

Tourists often look for information before deciding to visit a tourist place through the attributes of the destination. Information about these destination attributes can be searched through information on various media that can be claimed as a promotional event for a tourist spot [20], [21], [22], [23] Promoting the destination creates the destination positioning and branding, selecting the most appropriate markets [24]. Various information that can be accessed about a tourist place can be done by various interested parties, managers and even from previous visitors who have come and present their experiences on various social media [10], [6], [24]. TNBTS Managers TNBTS managers provide information and provide recommendations about lodging and others as a means of tourism promotion that makes it easier for tourists to find information about BTSNP tourism. Currently, complete information related to BTSNP tourism can be accessed easily via the internet, managed by local managers and governments, the traveller community, and individual content creators who share their experiences through social media and other media.

Destination attributes and promotion of tourist destinations offered are components of a marketing strategy that allows improving performance and destination branding efforts, leading to the number of visits or visit intentions. BTSNP is famous for its natural and cultural tourist attractions. The number of natural tourist spots that tourists can enjoy and the cultural activities of the Tengger people is still maintained and implemented until now through various information media as a means of promotion. Based on the description above, we need a model that analyzes the role of tourism product attributes and Tourism Promotion on destination branding and their implications for visiting tourist destinations in Bromo Tengger Semeru National Park.

\section{LITERATURE REVIEW}

\subsection{Destination Attributes}

Destination attributes [25], [6], [15], are all forms of services tourists enjoy since he leaves his residence while in the tourist destination visited until he returns to his place of origin. [16], also mentions that Destination Attributes is a collection of various products produced by companies that are given direct services to tourists when travelling. Three essential elements make up the product of the tourism industry [18], [11]. 
a. Destination Attraction is an object and attraction that is available as an attraction that tourists want to visit the country, city, or tourist spot. Attractions are grouped as follows: natural attractions (landscapes, natural scenery, and other geographical features of tourist destinations); built attractions (historical and modern architectural buildings, parks, gardens, specialty shops and themed retail areas); and other attractions that attract tourists to come to visit.

b. Destination facilities are all that can meet the needs of tourists while in the area of the tourist attractions visited. The components of the facility itself are as follows: 1) restaurants and other forms of eating places; 2) entertainment centers and other recreational facilities; 3) shopping centers, gift shops, art galleries and others; 4) other facilities such as public facilities, parking, and others; 5) other services such as information center, security center, and others.

c. Accessibilities is everything that can make it easy for tourists to come to visit a tourist place. Accessibility elements are: 1) Infrastructure (airport, railway line, seaport, toll road); 2) Equipment (size, speed, reach of public transportation facilities); 3) Operational factors (lines or other routes); 4) Government regulations (including supervision of the implementation of transportation arrangements).

d. Images are a concept that comes along after people perceive the products and services that the tourism sector presents. Generally, the mainframe of the destination image consists of the conceptual, emotional or total image

\subsection{Tourism Promotion}

Promotion is an effort made by the manager and local government in attracting tourists who will visit. Just like promotional efforts in the retail or service sector, promotional efforts [1] in the tourism industry include:

1. Advertising, BTSNP tourism managers do promotions through paid advertisements.

2. Sales promotion, BTSNP using promotion is holding tour packages.

3. Personal selling, managers promote BTSNP tourism through travel agents.

4. Public relations, managers and the government held a cultural event that would introduce BTSNP tourism.

5. Direct marketing, promotion efforts are made by the manager of BTSNP tourism, namely through the internet, which tourists directly access

\subsection{Destination Branding}

A brand is defined as something that can carry out the entire communication process a mixture of attributes, in the form of a logo or symbol that reflects a promise or emotional process between consumers and companies that create a valuable influence for stakeholders and consumers [26] . Destination branding is also defined as a name, symbol, logo, word mark or other image that can identify and distinguish a destination; the rest, promises a memorable tourist experience because of the uniqueness of a destination; which also serves to strengthen memory, memorable memories of a destination experience [8], [27] . The evaluation component of place brand effectiveness refers to research [28]. Presence refers to international status, how much people know the destination.

1. Place refers to the physical aspects of a tourist destination

2. Potential refers to the opportunity for the city to become more famous

3. Pulse, refers to how much someone is attracted to the city.

4. People, testing the local population in terms of openness, friendliness, and security issues in the city.

5. Prerequisites relate to the city's basic quality, standards and costs of accommodation and public comfort.

\subsection{Visit Intention}

The visiting decision is a theoretical adaptation of the purchase decision. Consumer purchasing behaviour is influenced by cultural, social and personal factors [29], [30], [31]. In tourist destinations, indicators of visit intention are described as follows [10], [32] [2] .

1. Destination area, namely knowledge of the area to be addressed,

2. Traveling Mode, namely the availability of means of transportation during the trip,

3. Time and Cost, namely the availability of time and costs for travelling,

4. Travel Agent, namely the availability of a travel provider,

5. Service Source, namely the variety of services available at the destination.

Based on the literature review, the conceptual framework of this research is presented in Figure 1. 


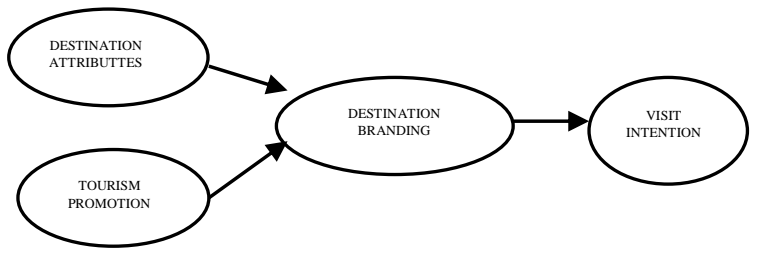

Figure 1. Conceptual Framework

\section{METHODOLOGY}

The research design is an explanatory research design that explains casual relationships (cause-effect) and tests the relationship between several variables through testing several hypotheses or explanatory research [33] . The population used for this study were tourists who had visited Bromo Tengger Semeru National Park with a sample size of 180 people with a purposive sampling method with specific considerations [34], provided that the respondent knows information about BTSNP and has been to BTSNP. The variable measurement scale used in this study is semantic differential. The semantic differential is one way to determine a score based on a bipolar assessment with a score interval of 1 to 10 , where the smallest score represents the most inappropriate answer.

The variables studied in this study are grouped into three types, namely: a) The independent variable is destination attribute test $\left(\mathrm{X}_{1}\right)$ which uses four indicators of destination attractiveness, facilities, accessibility, and images [18], [11], tourism promotion $\left(\mathrm{X}_{2}\right)$ measurement using indicators: [1], advertising, sales promotion, personal selling, public relation, direct marketing; intervening variable $(\mathrm{Z})$ destinations branding with six indicators [29], are the presence, the place, the potential, the pulse, the people, the prerequisite; and the dependent variable (Y) namely visit Intention as measured by five indicators, namely destination area, travelling mode, time and cost, travel agent, and service source [33], [35], [2] .

\section{RESULTS}

\subsection{Validity and reliability test}

It is known that each indicator (item) in the variable used has the result of Pearson's productmoment value with a significance of $0.000<0.05$ so that the indicators used in this research variable can be declared relevant and can be used as a tool in data collection. The validity test result of each indicator is presented in Table 1.

Table 1. Validity Test

\begin{tabular}{|c|c|c|c|c|c|}
\hline Variable & & Indicator & $\begin{array}{l}\text { Product } \\
\text { Moment } \\
\text { Pearson's }\end{array}$ & Sig. & Validity \\
\hline \multirow{4}{*}{$\begin{array}{l}\text { Destination } \\
\text { Attributes } \\
\text { (X1) }\end{array}$} & $\mathrm{X}_{1.1}$ & Attractiveness & 0.695 & 0.00 & $\begin{array}{l}<0.05 \\
\text { Valid }\end{array}$ \\
\hline & $\mathrm{X}_{1.2}$ & Facilities & 0.791 & 0.00 & $\begin{array}{l}<0.05 \\
\text { Valid }\end{array}$ \\
\hline & $\mathrm{X}_{1.3}$ & Accessbility & 0.821 & 0.00 & $\begin{array}{l}<0.05 \\
\text { Valid }\end{array}$ \\
\hline & $\mathrm{X}_{1.4}$ & Images & 0.821 & 0.00 & $\begin{array}{l}<0.05 \\
\text { Valid }\end{array}$ \\
\hline \multirow{5}{*}{$\begin{array}{l}\text { Tourism } \\
\text { Promotion } \\
\text { (X2) }\end{array}$} & $\mathrm{X}_{2.1}$ & Advertising & 0.501 & 0.00 & $\begin{array}{l}<0.05 \\
\text { Valid }\end{array}$ \\
\hline & $\mathrm{X}_{2.2}$ & $\begin{array}{l}\text { Sales } \\
\text { Promotion }\end{array}$ & 0.676 & 0.00 & $\begin{array}{l}<0.05 \\
\text { Valid }\end{array}$ \\
\hline & $\mathrm{X}_{2.3}$ & $\begin{array}{l}\text { Personal } \\
\text { Selling }\end{array}$ & 0.62 & 0.00 & $\begin{array}{l}<0.05 \\
\text { Valid }\end{array}$ \\
\hline & $\mathrm{X}_{2.4}$ & $\begin{array}{l}\text { Public } \\
\text { Relation }\end{array}$ & 0.666 & 0.00 & $\begin{array}{l}<0.05 \\
\text { Valid }\end{array}$ \\
\hline & $\mathrm{X}_{2.5}$ & $\begin{array}{l}\text { Direct } \\
\text { Marketing }\end{array}$ & 0.621 & 0.00 & $\begin{array}{l}<0.05 \\
\text { Valid }\end{array}$ \\
\hline \multirow{6}{*}{$\begin{array}{l}\text { Destination } \\
\text { Branding } \\
\text { (Z) }\end{array}$} & $\mathrm{Z}_{.1}$ & Presence & 0.68 & 0.00 & $\begin{array}{l}<0.05 \\
\text { Valid }\end{array}$ \\
\hline & $\mathrm{Z}_{.2}$ & Place & 0.78 & 0.00 & $\begin{array}{l}<0.05 \\
\text { Valid }\end{array}$ \\
\hline & $\mathrm{Z}_{3}$ & Potential & 0.493 & 0.00 & $\begin{array}{l}<0.05 \\
\text { Valid }\end{array}$ \\
\hline & $\mathrm{Z}_{4}$ & Pluse & 0.657 & 0.00 & $\begin{array}{l}<0.05 \\
\text { Valid }\end{array}$ \\
\hline & $\mathrm{Z}_{.5}$ & People & 0.623 & 0.00 & $\begin{array}{l}<0.05 \\
\text { Valid }\end{array}$ \\
\hline & $\mathrm{Z}_{6}$ & Prerequisite & 0.602 & 0.00 & $\begin{array}{l}<0.05 \\
\text { Valid }\end{array}$ \\
\hline \multirow{5}{*}{$\begin{array}{l}\text { Visit } \\
\text { Intention } \\
(\mathrm{Y})\end{array}$} & $\mathrm{Y}_{.1}$ & $\begin{array}{l}\text { Destination } \\
\text { Area }\end{array}$ & 0.614 & 0.00 & $\begin{array}{l}<0.05 \\
\text { Valid }\end{array}$ \\
\hline & $\mathrm{Y}_{.2}$ & $\begin{array}{l}\text { Traveling } \\
\text { Mode }\end{array}$ & 0.634 & 0.00 & $\begin{array}{l}<0.05 \\
\text { Valid }\end{array}$ \\
\hline & $\mathrm{Y}_{.3}$ & $\begin{array}{l}\text { Time and } \\
\text { Cost }\end{array}$ & 0.796 & 0.00 & $\begin{array}{l}<0.05 \\
\text { Valid } \\
\end{array}$ \\
\hline & $\mathrm{Y}_{.4}$ & Travel Agent & 0.686 & 0.00 & $\begin{array}{l}<0.05 \\
\text { Valid }\end{array}$ \\
\hline & $\mathrm{Y}_{.5}$ & $\begin{array}{l}\text { Service } \\
\text { Source }\end{array}$ & 0.619 & 0.00 & $\begin{array}{l}<0.05 \\
\text { Valid }\end{array}$ \\
\hline
\end{tabular}

Source: Data analysis, 2020

The results of the reliability test in Table 2 indicate that the data obtained are reliable because all the values of Cronbach's Alpha variables exceed the limit of 0.6 , so the data obtained can be declared reliable or feasible as a tool in data collection below.

Table 2. Reliability Test

\begin{tabular}{|l|c|l|c|c|}
\hline \multicolumn{1}{|c|}{ Variable } & $\begin{array}{c}\text { Cronbach's } \\
\text { Alpha }\end{array}$ & $\begin{array}{l}\text { Cut } \\
\text { Off }\end{array}$ & $\begin{array}{c}\text { No. of } \\
\text { Item }\end{array}$ & Reliability \\
\hline Destination Attributes (X1) & 0.654 & $>0.6$ & 3 & Reliable \\
\hline Tourism Promotion (X2) & 0.674 & $>0.6$ & 5 & Reliable \\
\hline Destination Branding (Z) & 0.681 & $>0.6$ & 6 & Reliable \\
\hline Visit Intention (Y) & 0.727 & $>0.6$ & 5 & Reliable \\
\hline
\end{tabular}




\subsection{Classic Assumption Test}

From the normality test, it can be seen that the probability or significance value for each variable is $0.185\left(\mathrm{X}_{1}\right) ; 0.191\left(\mathrm{X}_{2}\right) ; 0.235(\mathrm{Z})$; and $0.251(\mathrm{Y})$, which are all more than 0.05 , so it can be stated that the data in this study were normally distributed. There is no multicollinearity between the independent variables because it shows a VIF value of less than ten, where the VIF values for $X_{1}$ and $X_{2}$ are the same as 1.908. The data distribution image in the two equations also shows that heteroscedasticity does not occur because the data distribution does not form a particular line or there is no clear pattern. The points spread above and below the zero on the Y-axis.

\subsection{Path Analysis}

After going through the instrument test stage and assuming the feasibility of the regression model, then a path analysis is carried out. Path analysis deals with the study of the dependence of a dependent variable on one or more independent or intervening variables with the aim of finding out how much influence the independent or intervening variable has on the dependent variable. The results of the path analysis between the independent variables, namely destination attribute and promotions, and the intervening variable, namely destinations branding, and the dependent variable, namely visit Intention, can be seen in the Figure 2 and Table 3.

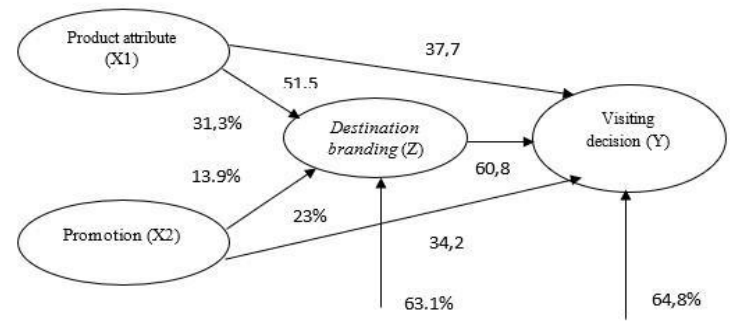

Figure 2. Path Analysis Result

Table 3. Path Analysis Result

\begin{tabular}{|c|c|c|cc|c|}
\hline \multicolumn{2}{|c|}{ Standardized } & \multirow{2}{*}{ Sig. } & \multicolumn{2}{c|}{$\boldsymbol{\alpha}$} & \multirow{2}{*}{ Result } \\
\cline { 1 - 2 } Path & $\begin{array}{c}\text { Beta } \\
(\boldsymbol{\beta})\end{array}$ & & & \\
\hline $\mathrm{X} 1 \rightarrow \mathrm{Z}$ & 0.515 & 0.000 & $<$ & 0.05 & Significant \\
\hline $\mathrm{X} 2 \rightarrow \mathrm{Z}$ & 0.230 & 0.004 & $<$ & 0.05 & Significant \\
\hline $\mathrm{X} 1 \rightarrow \mathrm{Y}$ & 0.377 & 0.000 & $<$ & 0.05 & Significant \\
\hline $\mathrm{X} 2 \rightarrow \mathrm{Y}$ & 0.342 & 0.000 & $<$ & 0.05 & Significant \\
\hline $\mathrm{Z} \rightarrow \mathrm{Y}$ & 0.608 & 0.000 & $<$ & 0.05 & Significant \\
\hline$\varepsilon 1$ & 0.631 & - & & - & - \\
\hline$\varepsilon 2$ & 0.648 & - & & - & - \\
\hline
\end{tabular}

Source: Data analysis, 2020
Based on the path coefficients in the Table 3, the equations that can be formed are as follows:

$$
\begin{gathered}
\mathrm{Z}=1,324+0,515 \mathrm{X} 1+0,230 \mathrm{X} 2+0,631 \varepsilon 1 \\
\mathrm{Y}=0,911+0,377 \mathrm{X} 1+0,342 \mathrm{X} 2+0,608 \mathrm{Z}+0,648
\end{gathered}
$$$$
\varepsilon 2
$$

\section{DISCUSSION}

\subsection{Destination Atributtes Effects on Destinations Branding}

The results showed that the destination attributes in the tourist attractions of Bromo Tengger Semeru National Park tended to have a strong influence on the destination's branding by $51.5 \%$. The destination attribute test variable has a coefficient value of 0.515 with a significance value of less than $5 \%$. Then $\mathrm{Ha}$ is accepted, which means the destination attributes significantly affect the tourist destinations branding Bromo Tengger Semeru National Park.

In line with the research [4], [6], [9] , the attributes that exist in a tourist destination can be an essential component in creating destinations branding. More specifically, research on tourism in the natural mountains [36], states that the attributes in a destination consisting of physical and invisible attributes can create a mountain tourism destination branding that is different from the others. According to [5], which is included in the primary attributes of tourism products, namely tourist attractions or tourist attractions, accommodation facilities and services, transportation facilities and other services, human resources, other service facilities, institutional elements.

\subsection{Tourism Promotion Effects on Destinations Branding}

The research shows that the promotion carried out by the tourist attractions of Bromo Tengger Semeru National Park tends to have a moderate influence on destination branding by $23 \%$. The promotion variable has a coefficient value of 0.230 with a significance value of less than $5 \%$. So, Ha is accepted, which means that the promotion significantly affects the tourist destinations branding Bromo Tengger Semeru National Park.

According to [33], promoting a tour allows tourist objects to increase their visits and tourists. Therefore, gaining the trust of tourists is one of the marketing targets that need to be targeted by tourist objects. 
Generating trust in tourists takes a stimulus or things that can stimulate the emergence of imagination and trust in these tourist attractions. According to [5], [6] the promotion will be "something" attractive to prospective tourists. Promotion is the promise of a place or means of giving something to consumers.

\subsection{Destination Atributtes Effects on Visit Intention}

The research conducted showed that the destination attributes in the Bromo Tengger Semeru National Park tourist attraction had a strong tendency of influence of $37.7 \%$. The variable destination attribute tests that affect visit intention has a coefficient value of 0.377 with a significance value of less than $5 \%$. Then Ha is accepted, which means that destination attributes significantly affect the visit intention of Bromo Tengger Semeru National Park tourism.

[20], states that currently, there are so many tour packages that provide tour trips in various interesting tourist objects around us. Destination attributes are one of the essential elements in marketing. No matter how valuable a tourist destination is, if it is not known by tourists, the benefits of these tourist destinations will not be known and may not be visited by tourists. One part of tourism marketing is the attribute of tourism [12].

\subsection{Tourism Promotion Effects on Visit Intention}

The research shows that the promotion carried out by the Bromo Tengger Semeru National Park tourist attraction has an influence tendency of $34.2 \%$. The promotion variable on visit intention has a coefficient value of 0.342 with a significance value of less than 55 , which means that promotion significantly affects visit intention to visit Bromo Tengger Semeru National Park.

[10], [37] Stated that promotion influences the decision to visit tourists. The effect of promotion on visit intention will increase knowledge and information from potential tourists to be able to visit these tourist attractions. [12], adds that the development of the tourism sector in a country will attract other sectors to develop because its products are needed to support the tourism industry, such as sectors, increasing employment opportunities in plantations, people's handicrafts, etc.

\subsection{Destinations Branding Effects on Visit intention}

The research shows that the destination's branding in the Bromo Tengger Semeru National Park tourist spot tends to strongly influence a visit intention of $60.8 \%$. The variable of destinations branding to visit Intention has a coefficient value of 0.608 with a significance value of less than $5 \%$. Ha was accepted, which means that the destination's branding had a significant effect on Bromo Tengger Semeru National Park tourism visit intention.

When someone goes on a tour, he will look for exciting tourist destinations [33]. This is where the role of tourism marketing communication is. The more messages are delivered to the public, the more consumers (tourists) will receive the message. The real challenge is when the audience accepts the message whether they will want to and happily apply the message to themselves or not. Therefore, tourism industry marketers must be wiser to carry out a branding tactic for their destinations. Meanwhile, [20] says that tourism marketing must provide transparent and well-managed branding for tourism products.

\section{CONCLUSION}

Based on the results of the analysis that has been carried out in this study, the following conclusions can be drawn: destination attributes have a significant effect on the destination's branding of BTSNP tours; tourism promotion has a significant effect on the tourist destinations branding BTSNP; destination attribute tests have a significant effect on visit intention to BTSNP; tourism promotion has a significant effect on visit intention to BTSNP, and the last destination's branding has a significant effect on visit intention to BTSNP.

From the results of this research analysis, various strategies can be formulated that can increase the number of visits by managers and policymakers at BTSNP:

1. Increase the attractiveness of the destination, complete the facilities needed by tourists and improve all infrastructure that can help the accessibility to BTSNP tourist destinations;

2. Compiling more vigorous promotional tools, especially digital marketing that is in accordance with the current tourism promotion phenomenon, and

3. Designing the right destination branding strategy for BTSNP ecotourism while maintaining natural 
preservation and panoramic views that have been an icon of tourism in East Java

\section{REFERENCES}

[1] Kotler, P., Makens, J. C., Bowen, J. T., and Baloglu, S, Marketing for hospitality and tourism. Pearson Education, 2018.

[2] Phillips, W., and Jang, S, "Destination image and visit intention: Examining the moderating role of motivation," Tourism Analysis, 12(4), 319-326, 2007.

[3] Verma, V. K., and Chandra, B, “An application of theory of planned behavior to predict young Indian consumers' green hotel visit intention," Journal of Cleaner Production, 172, 1152-1162, 2018.

[4] Balakrishnan, M. S., Nekhili, R., and Lewis, C, "Destination brand components," International Journal of Culture, Tourism and Hospitality Research, 2011.

[5] Fuadillah, N., and Murwatiningsih, M, "The Effect of Place Branding, Promotion and Tourism Product Attribute on Decision to Visit Through The Destination Image," Management Analysis Journal, 7(3), 328-339, 2018.

[6] Hasanah, K., Sudaryanto, and Wulandari, G. A, "Pengaruh Atribut Wisata Dan Promosi Terhadap Keputusan Berkunjung Pada Wisata Gunung Bromo Melalui Destination Branding" UNEJ, 2020.

[7] Morgan, N., Pritchard, A., and Pride, R, Destination branding. Routledge, 2007.

[8] Blain, C., Levy, S. E., and Ritchie, J. R. B, "Destination branding: Insights and practices from destination management organizations," Journal of Travel Research, 43(4), 328-338, 2005.

[9] Qu, H., Kim, L. H., and Im, H. H, "A model of destination branding: Integrating the concepts of the branding and destination image," Tourism Management, 32(3), 465-476, 2011.

[10] Bonn, M. A., Cho, M., Lee, J. J., and Kim, J. H, "A multilevel analysis of the effects of wine destination attributes on travel constraints and revisit intention," International Journal of Contemporary Hospitality Management, 2016.

[11] Shuib, A., Mahdzar, M., Ramachandran, S., Herman, S., and Afandi, M, "The Role of
Destination Attributes and Memorable Tourism Experience in Understanding Tourist Revisit Intentions December 2017, 2015. https://doi.org/10.5829/idosi.aejaes.2015.15.s.20 5

[12] Yusuf, A, "Pengaruh atribut produk wisata terhadap place branding dan implikasinya terhadap keputusan mengunjungi destinasi wisata pantai (survey terhadap wisatawan nusantara di kabupaten karawang)," Value: Journal of Management and Business, 1(1), 2016.

[13] Ariesta, D., Sukotjo, E., and Suleman, N. R, "The Effect Of Attraction, Accessibility And Facilities On Destination Images And It's Impact On Revisit Intention In The Marine Tourism Of The Wakatobi Regency," Internatioan Journal of Scientific and Technology Researh, 9(3), 2020.

[14] Jumanazarov, S., Kamilov, A., and Kiatkawsin, K. "Impact of Samarkand's Destination Attributes on International Tourists' Revisit and Word-of-Mouth Intention," Sustainability, 12(12), 5154, 2020.

[15] Singh, R., and Singh, J, "Destination attributes to measure tourist revisit intention: A scale development," Global Business Review, 20(2), 549-572, 2019.

[16] Gannon, M. J., Baxter, I. W. F., Collinson, E., Curran, R., Farrington, T., Glasgow, S., Godsman, E. M., Gori, K., Jack, G. R. A., and Lochrie, S, "Travelling for Umrah: destination attributes, destination image, and post-travel intentions," The Service Industries Journal, 37(7-8), 448-465, 2017.

[17] Johann, M., and Ghose, S, Measuring Tourist Satisfaction with Destination Attributes, 2018.

[18] Kozak, M, "Measuring tourist satisfaction with multiple destination attributes," Tourism Analysis, 7(3-4), 229-240, 2003.

[19] Middleton, V. T. C., and Clarke, J. R, Marketing in travel and tourism, Routledge, 2012.

[20] Avinda, C. B., Sudiarta, I. N., and Karini, N. M. $\mathrm{O}$, "Strategi promosi Banyuwangi sebagai destinasi wisata (studi kasus pada Dinas Kebudayaan dan Pariwisata)," Jurnal IPTA (Industri Perjalanan Wisata), 4(1), 55-60, 2016.

[21] Maulida, K., and Pibadi, J. D, "Pembuatan Katalog Dengan Aplikasi Coreldraw Sebagai Media Promosi Untuk Meningkatkan Kunjungan 
Di Wisata Blayu Lesti Lestari Wajak Malang," Jurnal Aplikasi Bisnis, 2(1), 5-8, 2017.

[22]Pai, F.-Y., Chen, C.-P., Yeh, T.-M., and Metghalchi, M, "The effects of promotion activities on consumers' purchase intention in chain convenience stores," International Journal of Business Excellence, 12(4), 413-432, 2017.

[23] Wolah, F. F. C, "Peranan promosi dalam meningkatkan kunjungan wisatawan di Kabupaten Poso.," Acta Diurna Komunikasi, 5(2), 2016.

[24] Morrison, A. M, "Marketing and managing tourism destinations," In Marketing and Managing Tourism Destinations, 2013, https://doi.org/10.4324/9780203081976.

[25] Chahal, H., and Devi, A, "Destination Attributes and Destination Image Relationship in Volatile Tourist Destination: Role of Perceived Risk," 14, 1-19, 2015, https://doi.org/10.1177/0972622520150203.

[26] Avraham, E., and Ketter, E, "Marketing and Destination Branding," In Tourism Marketing for Developing Countries, (pp. 39-66), 2016, Springer.

[27] Ritchie, J. R. B., and Ritchie, J. R. R, "The branding of tourism destinations," Annual Congress of the International Association of Scientific Experts in Tourism, Marrakech, Morocco, 1-31, 1998.

[28] Ashworth, G., and Kavaratzis, M, Towards effective place brand management: Branding European cities and regions. Edward Elgar Publishing, 2010.

[29] Bamossy, G. J., and Solomon, M. R, Consumer behaviour: A European perspective. Pearson Education, 2016.

[30] Jefkins, F., and Jefkins, F," Consumer Behaviour. In Modern Marketing Communications, 1990, https://doi.org/10.1007/978-94-011-6868-7_14.

[31] Peter, J. P., and Olson, J. C, Consumer Behavior and Marketing. In Mc (Ed.), Dana (Ninth). Mc Graw Hill, 2010.

[32] Damanik, J., and Weber, H. F, Perencanaan ekowisata dari teori ke aplikasi, 2006.

[33] Solimun, A. M. P. S, Metode Partial Least Square-PLS. Malang : CV Citra Malang, 2010.

[34] Sugiyono, Metode Penelitian Kuantitatif, Kualitatif dan RandD (4th ed.). Alfabeta, 2017.
[35] Kim, S., and Jun, J, "The impact of event advertising on attitudes and visit intentions," Journal of Hospitality and Tourism Management, 29, 1-8, 2016.

[36] Williams, P. W., Gill, A. M., and Chura, N, "Branding mountain destinations: The battle for placefulness," Tourism Review, 2004.

[37] Tobias-Mamina, R. J., Kempen, E., Chinomona, R., and Sly, M. (n.d.), The Influence of Instagram Advertising on Destination Visit Intention. 